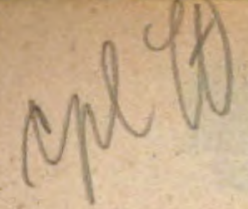



PUBLIE PAR

\title{
LE COMITÉ HISTORIQUE
}

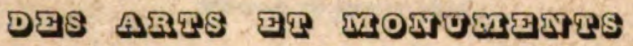

\section{TROISIÉME VOLUME}

\section{PARIS}

IMPRIMERIE ADMINISTRATIVE DE PAUL DUPONT

Rue de Grenelle-Saint-Honoré, no 55

1844 et 1845 